\title{
ANALIZA POTENCJALNYCH KORZYŚCI ORAZ NEGATYWNYCH KONSEKWENCJI WDROŻENIA NORM LCR ORAZ NSFR W BANKACH EUROPEJSKICH
}

\section{Wprowadzenie}

Pakiet reform regulacyjnych, nazywany potocznie Bazyleą III, zawiera między innymi nowe wymogi ilościowe związane z płynnością banku. Są to dwa wskaźniki norma płynności krótkoterminowej LCR oraz norma płynności długoterminowej NSFR. Przyjęcie Bazylei III poprzedziło zwrócenie się w 2009 r. przez Bazylejski Komitet ds. Nadzoru Bankowego (BKNB) do krajowych organów nadzorczych z zapytaniem o stosowane narzędzia kontroli płynności pojedynczych banków oraz całego sektora. W odpowiedzi przedstawiono 25 modeli monitorowania płynności w sektorze bankowym, stąd intencją BKNB stało się ujednolicenie tych procedur lub przynajmniej uzgodnienie minimalnego obligatoryjnego zestawu narzędzi wykorzystywanego przez każdy nadzór krajowy. W sensie kwantytatywnym właśnie LCR oraz NSFR mają stać się pewnym minimum i jednocześnie podstawą budowy procesu zarządzania płynnością w banku'.

Niniejsze opracowanie stawia sobie za cel identyfikację korzyści z tytułu wprowadzenia w życie nowych narzędzi zarządzania ryzykiem płynności w bankach oraz analizę potencjalnych negatywnych konsekwencji wdrożenia tych wskaźników, zarówno z perspektywy sektora bankowego, jak i sfery realnej gospodarki. Przedmiotem badania uczyniono wyłącznie banki uniwersalne i wnioski sformułowane w artykule odnoszą się do tej części sektora bankowego - bankowość spółdzielcza i specjalistyczna wymagają odrębnej analizy.

* Szkoła Główna Handlowa w Warszawie, Kolegium Ekonomiczno-Społeczne.

1 Szerszy katalog wskaźników opisujących płynność banku, zawartych w bazie Bankscope i wykorzystywanych w praktyce oceny banków, przedstawiono w: K. Kochaniak, Ptynność sektora bankowego $w$ Polsce i znaczenie norm nadzorczych, „Annales Universitatis Mariae Curie Sklodowska” 2010, Lublin - Polonia, VOL. XLIV, 2 SECTIO H, s. 208. 


\section{Istota norm płynności LCR oraz NSFR}

Normę płynności krótkoterminowej, czyli LCR (Liquidity Coverage Ratio), zdefiniować można jako:

$$
L C R=\frac{H Q L A}{N C O}
$$

gdzie:

HQLA - płynne aktywa wysokiej jakości (High Quality Liquid Assets),

NCO - wypływy netto w ciągu najbliższych $30 \mathrm{dni}$ (Net Cash Outflows Over a 30-day time period).

LCR obowiązuje od stycznia 2015 r., jednak w wyniku uzgodnień poczynionych jeszcze na początku 2013 r. wdrożenie następować będzie stopniowo, zgodnie z harmonogramem przedstawionym w tabeli 1.

Tabela 1. Harmonogram wdrażania wymogu LCR

\begin{tabular}{|l|c|c|c|c|c|}
\cline { 2 - 5 } \multicolumn{1}{c|}{} & 01.01 .2015 & 01.01 .2016 & 01.01 .2017 & 01.01 .2018 & 01.01 .2019 \\
\hline Minimalna wartość LCR & $60 \%$ & $70 \%$ & $80 \%$ & $90 \%$ & $100 \%$ \\
\hline
\end{tabular}

Źródło: BIS, Basel III: the Liquidity Coverage Ratio and liquidity risk monitoring tools, January 2013, s. 2.

Kalkulacja HQLA opiera się na zasadzie przypisywania tym większej wagi poszczególnym rodzajom aktywów, im aktywa te są bardziej płynne. Z kolei im bardziej stabilna pozycja pasywów w ramach NCO, tym mniejsza waga (w tym mniejszym stopniu zobowiązanie to ma być pokryte płynnymi środkami z zasobu HQLA).

Bank de facto nie ma możliwości pełnego kontrolowania wydatków. Może jednak przygotować się na wypadek, gdyby deponenci zażądali natychmiastowego zwrotu swoich środków i jednocześnie nie byłoby możliwości uzupełnienia luki depozytami o porównywalnym koszcie. Tą sferą oddziaływania banku jest zasób płynnych aktywów HQLA, którego zasady dekompozycji przedstawiono w tabeli 2.

Tabela 2. Ogólna struktura HQLA

\begin{tabular}{|c|c|c|}
\hline & \multicolumn{2}{|c|}{ Struktura oraz limity } \\
\hline \multirow{3}{*}{ HQLA } & \multicolumn{2}{|c|}{ Poziom 1 (brak limitu) } \\
\hline & \multirow{2}{*}{$\begin{array}{l}\text { Poziom } 2 \\
\text { (do 40\% HQLA) }\end{array}$} & Poziom 2A (jako komponent poziomu 2) \\
\hline & & Poziom 2B (jako komponent poziomu 2) (do 15\% HQLA) \\
\hline
\end{tabular}

Źródło: Opracowanie własne. 
W skład aktywów należących do poziomu 1 wchodzą środki pieniężne, środki zdeponowane w banku centralnym, w tym na pokrycie rezerw (np. rezerwy obowiązkowej) oraz papiery wartościowe wyemitowane lub gwarantowane przez rządy państw lub banki centralne, będące podmiotami, którym przypisano zerową wagę ryzyka (zgodnie z metodą standardową opisaną w Bazylei II). Wymienione powyżej papiery wartościowe muszą być przedmiotem obrotu na płynnych rynkach repo lub rynkach kasowych, odznaczających się niskim poziomem koncentracji. W grę wchodzą także aktywa notowane na płynnych rynkach, gdzie do ryzyka kraju nie jest przypisana zerowa waga (dotyczy wyłącznie banków, które rejestrują odpływ środków, głównie w walucie danego kraju). Poziom 2A obejmuje papiery dłużne emitowane przez jednostki samorządu terytorialnego, listy zastawne oraz obligacje korporacyjne. W ramach zasobu $2 \mathrm{~A}$ funkcjonować mogą także papiery wartościowe wyemitowane lub gwarantowane przez rządy, banki centralne oraz podmioty sektora publicznego i banki rozwoju wielostronnego, którym przypisana jest waga 20\%, zgodnie z zasadami Bazylei II. Muszą to być jednocześnie instrumenty notowane na płynnych rynkach finansowych o niskim poziomie koncentracji. $\mathrm{W}$ okresie napięć płynnościowych (historycznie) aktywa te powinny odznaczać się niską zmiennością cen (maksymalnie 10-procentowy spadek ceny w 30-dniowym okresie napięć). W skład HQLA (poziom 2A) nie wchodzą jednak papiery dłużne emitowane przez instytucje finansowe i kredytowe, gwarantowane przez skarb państwa. Emisje takie mają bowiem miejsce w okresie kryzysu i często są elementem programu ratunkowego. Do zasobu 2A zalicza się również obligacje korporacyjne (w tym commercial papers) i listy zastawne wyemitowane przez inny bank. Obligacje korporacyjne muszą posiadać rating zewnętrzny na poziomie nie niższym od AAnadany przez ECAI lub (w wypadku braku zewnętrznej oceny ratingowej) rating wewnętrzny $z$ PD na poziomie odpowiadającym PD charakteryzującego papiery dłużne $\mathrm{z}$ ratingiem zewnętrznym nie gorszym niż AA-. Podobnie jak papiery rządowe, obligacje korporacyjne oraz listy zastawne powinny odznaczać się wysoką płynnością i relatywnie niską zmiennością cenową (maksymalny spadek wartości w 30-dniowym okresie napięć płynnościowych to $10 \%$ ). Z kolei poziom $2 \mathrm{~B}$ składa się z obligacji korporacyjnych (innych niż emitowane przez instytucje kredytowe lub finansowe) o niższym ratingu niż te zaliczone do poziomu $2 \mathrm{~A}$ - pod uwagę brane są obligacje o ratingu zewnętrznym przyznanym przez uznaną agencję ratingową nie gorszym niż BBB- i nie lepszym od A+ lub ratingu wewnętrznym $z$ ekwiwalentnym PD (dla tych papierów wartościowych waga wynosi 50\%), obligacje wyemitowane w ramach sekurytyzacji portfela kredytów mieszkaniowych (tzw. RMBS, czyli Residential Mortgage Backed Securities) $\mathrm{z}$ wagą $25 \%$ oraz nieobciążone akcje $\mathrm{z}$ wagą $50 \%$. RMBS muszą charakteryzować się ratingiem nie niższym od AA, a redukcja ich 
ceny w 30-dniowym okresie napięć płynnościowych nie powinna być większa niż 20\% (analogiczną zmiennością mają charakteryzować się obligacje korporacyjne). Aktywami bazowymi dla emisji RMBS nie mogą być produkty strukturyzowane ${ }^{2}$. W skład zasobu 2B zaliczone mogą być również akcje, o ile nie zostały wyemitowane przez instytucje finansowe lub kredytowe, notowane na uznanych rynkach giełdowych, wchodzące w skład głównego indeksu giełdowego, dla których redukcja ceny w okresie napięć płynnościowych nie przekroczyła $40 \%$.

Bank odznaczający się satysfakcjonującym poziomem LCR to instytucja posiadająca nieobciążone, płynne aktywa odznaczające się niskim ryzykiem kredytowym o wartości adekwatnej do pokrycia prognozowanego odpływu środków (netto) w ciągu 30-dniowego okresu napięć rynkowych. Celem wprowadzenia LCR było pobudzenie banków do takiej przebudowy struktur swoich bilansów, aby we wspomnianym okresie napięć płynnościowych nie doszło do zbyt dużego obciążenia banku centralnego zadaniem podtrzymywania płynności w poszczególnych bankach. Scenariusz szokowy opierał się na wydarzeniach z początkowej fazy globalnego kryzysu finansowego. Okazało się wówczas, że kryzys płynnościowy to nie tylko krótkotrwałe (determinowane przyczynami stricte technicznymi) przerwy w funkcjonowaniu systemu kojarzenia banków odznaczających się nadpłynnością z bankami raportującymi niedobory płynności, ale długotrwały stan braku wzajemnego zaufania między instytucjami kredytowymi, wynikający ze wzrostu ryzyka kredytowego lub brak możliwości jego oszacowania. Wspomniany scenariusz szokowy uwzględnia jednoczesne wystąpienie następujących zdarzeń3:

- obniżenie ratingu banku o trzy klasy (i w związku z tym uwzględnienie dodatkowych wymogów w zakresie depozytów zabezpieczających realizację zawartych transakcji),

- wycofanie określonej części depozytów detalicznych (run na banki),

- utrata zdolności pozyskania środków na hurtowym rynku finansowym oraz ograniczenie możliwości zaciągnięcia długu zabezpieczonego aktywami (on a term basis),

- wzrost zmienności rynku, co ma wpływ na jakość i wartość zabezpieczenia, a także potencjalną zmianę wskaźników korekty w transakcjach na rynku terminowym,

\footnotetext{
2 Pod uwagę mogą zostać wzięte tylko te RMBS, których emisję oparto na kredytach hipotecznych z pełnym regresem, bez klauzuli umożliwiającej wykorzystanie ich na potrzeby krótkiej sprzedaży. D. Smith, J. Jennings-Mares, Liquidity Coverage Ratio: New Basel Measurement Published, Morrison-Foerster, www. mofo.com, dostęp 10.10.2013.

3 Possible further changes to the Capital Requirements Directive, Commission Services Staff Working Document EU, November 2011.
} 
- wzrost wykorzystania przyznanych, ale dotychczas niewykorzystywanych przez klientów linii kredytowych,

- konieczność realizacji określonych transakcji (mimo że formalnie bank nie jest do tego zobowiązany) ze względu na potencjalny wzrost ryzyka reputacyjnego,

- inne (w tym ograniczenia w zakresie konwersji walut itp.).

Normę płynności długoterminowej stanowi wskaźnik NSFR (Net Stable Funding Ratio $)^{4}$ :

$$
N S F R=\frac{A A S F}{R A S F}
$$

AASF - dostępna kwota stabilnych źródeł finansowania,

RASF - suma pozycji wymagających pokrycia stabilnymi źródłami finansowania.

W tym wypadku poszczególne pozycje aktywów i pasywów, podobnie jak miało to miejsce dla HQLA i NCO, korygowane są wagami. W ramach dostępnych źródeł finansowania (AASF) obowiązuje zasada, iż im bardziej stabilny rodzaj pasywów, tym wyższa waga. $Z$ kolei RASF to suma ważonych aktywów, wymagających pokrycia stabilnymi źródłami finansowania (im bardziej płynna kategoria aktywów, tym niższa waga).

Dalekosiężnym celem wprowadzenia NSFR jest zmiana struktury finansowania banków z opartej na krótkoterminowych, odnawialnych depozytach, zwykle rolowanych na rynku międzybankowym, na depozyty średnio- i długoterminowe oraz długoterminowe papiery dłużne, instrumenty quasi kapitałowe oraz fundusze własne (o ile, oczywiście, banki te zamierzają budować portfel ekspozycji długoterminowych). Chodzi przede wszystkim o to, aby portfele kredytów (obligacji) długoterminowych nie były finansowane wielokrotnie rolowanymi depozytami o skrajnie krótkich okresach (np. overnight na rynku międzybankowym). NSFR ma również ograniczyć zbyt dużą zależność wielu instytucji kredytowych od hurtowego rynku pieniężnego, która narasta w okresie dobrej koniunktury i nadpłynności sektora bankowego, a przynosi szczególnie negatywne skutki w czasie napięć, w tym wywołanych spadkiem wzajemnego zaufania między bankami. Zaobserwować można w tym wypadku swoistą procykliczność - w okresie koniunktury rośnie skala operacji na rynku międzybankowym i udział tej formy finansowania w bilansach banków, zaś w okresie dekoniunktury udział ten gwałtownie maleje. Podobnie jak w wypadku wskaźnika LCR, sposób estymacji NSFR podyktowany jest intencją uchronienia instytucji kredytowej przed scenariuszem szokowym - chodzi tu jednak w większym stopniu o szok

\footnotetext{
4 Dokładną metodologię kalkulacji NSFR opracowano dopiero w październiku 2014 r. - BIS, Basel III: the net stable funding ratio, October 2014.
} 
idiosynkratyczny, związany ze znaczącym wzrostem ryzyka kredytowego konkretnej instytucji kredytowej.

\section{Wpływ wprowadzenia norm LCR oraz NSFR na banki europejskie}

Wprowadzenie norm płynności LCR oraz NSFR ma na celu uodpornienie systemu bankowego na ograniczenie dostępu do finansowania zewnętrznego przy jednoczesnym ustabilizowaniu rentowności sektora, co łącznie powinno zmniejszyć skalę procykliczności w oddziaływaniu sektora bankowego na sferę realną gospodarki.

Wprawdzie przez cały okres prac nad LCR miało miejsce odwołanie do napięć płynnościowych w systemie bankowym, które odnotowano w latach 2007 i 2008, tym niemniej systematycznie, aż do stycznia 2013 r., zmniejszano wskaźniki korekty i poszerzano spektrum aktywów tworzących HQLA, jednocześnie zwiększając wskaźniki korekty dla NCO. Łącznie prowadziło to do zwiększenia wartości wskaźnika LCR i obniżenia motywacji banków do redukcji ryzyka płynności poprzez konwersję części mniej płynnych aktywów na HQLA, tudzież zmianę struktury depozytów. Równocześnie w styczniu 2013 r. zdecydowano się na wprowadzenie stopniowego (a nie jednorazowego) harmonogramu dojścia do wymaganej wartości LCR, czyli 1,0, co łącznie sprawia, że trudno merytorycznie wytłumaczyć tę liberalizację podejścia BKNB (normy zmieniane są stosownie do możliwości osiągniecia ich przez banki, a nie zgodnie z zasadą, iż ich wdrożenie stanie się istotnym środkiem zapobiegawczym przed kolejnym kryzysem płynnościowym).

Być może stopniowe zwiększanie wymaganego poziomu wskaźnika LCR oraz kolejne jego redefiniowanie wynikało z niedoboru zasobu HQLA w bilansach banków. Co interesujące, niedobór ten (dla LCR $=100 \%$ ) w bankach europejskich (badaniem w kwietniu 2012 r. objęto 158 banków w UE, w tym 48 dużych) zwiększył się pomiędzy grudniem 2009 r. i czerwcem 2011 r. o ok. 15\%, tj. z 1,0 tryliona EUR do 1,15 tryliona EUR. Niedobór wzrósł, mimo że w badanym okresie banki europejskie zwiększyły zasób HQLA o ok. 0,8 tryliona EUR. Stało się to wskutek znaczącego przyrostu prognozowanych wydatków (wypływów) - łącznie o ok. 1,5 tryliona EUR 5 . W tym samym okresie średnia wartość LCR wzrosła z 67\% do 71\%. Wspomniane

\footnotetext{
5 New Bank Liquidity Rules: Dangers Ahead, EBA, A Position Paper by EBA's Banking Stakeholder Group, October 2012, s. 4, www.eba.europa.eu, dostęp 09.02.2015.
} 
powyżej stopniowe zwiększanie wymogu ma na celu neutralizację potencjalnego zagrożenia w postaci substytucji części portfela kredytowego płynnymi aktywami.

W systemach finansowych opartych na kredycie bankowym jako źródle finansowania przedsiębiorstw relatywnie niewielkie znaczenie przynależne jest papierom dłużnym oraz akcjom, zwłaszcza tym, które podlegają codziennej wycenie (MTM), notowane są na płynnych rynkach i posiadają ocenę agencji ratingowej o statusie ECAI. W tym wypadku zasób HQLA tworzony może być głównie przez obligacje emitowane przez skarb państwa, bank centralny oraz podmioty sektora publicznego. Sytuacja taka stwarza naturalny dodatkowy popyt na te papiery, a oczekiwane obniżenie rentowności nie stanowić będzie bodźca dla redukcji podaży. Ponadto spodziewać się można reorientacji polityki kredytowej banków, które chętniej będą angażować się w papiery dłużne (a te nie są raczej emitowane przez podmioty MSP) niż udzielać kredytów (chyba, że powstanie płynny rynek wtórny kredytów bankowych na wzór segmentu kredytów konsorcjalnych). Tym samym systemy finansowe o cechach bliskich modelowi kontynentalnemu zaczną zapewne ewoluować w kierunku modelu anglosaskiego. Dotyczyć to może w szczególności systemów bankowych w krajach zaliczanych do grupy Emerging Markets ze słabo rozwiniętych rynkiem kapitałowym oraz systemów, w których dominującą rolę odgrywają banki globalne z niedoborem stabilnych źródeł finansowania ${ }^{6}$. Paradoksalnie więc norma, która miała zwiększyć stabilność systemu finansowego, przyczynić się może do „urynkowienia” ryzyka kredytowego, co z kolei zidentyfikowano jako jedną z przyczyn ostatniego kryzysu. Podsumowując, norma LCR i sposób estymacji HQLA de facto nie spowodują większych zmian w polityce kredytowej banków funkcjonujących w systemach o cechach modelu anglosaskiego, który to model oceniany jest jako bardziej kryzysogenny niż model anglosaski (kryzysy ostatnich 30 lat potwierdzają tę tezę).

Pozytywnie ocenić należy kwestię równouprawnienia ocen nadawanych przez zewnętrzne agencje ratingowe oraz przez banki (ratingi wewnętrzne), co jest wyrazem realizacji polityki zmierzającej do ograniczenia roli agencji ratingowych ${ }^{7}$. Na podkreślenie zasługuje również idea umożliwienia obiektywnej oceny płynności banku, dzięki wprowadzeniu systemu wag, uniemożliwiającego subiektywną klasyfikację aktywów według ich płynności oraz pasywów według ich stabilności.

Wprowadzenie LCR szczególnie negatywnie wpływa na banki, które dotychczas w znaczącym stopniu finansowały swoją działalność na hurtowym rynku międzybankowym. Wynika to z relatywnie niekorzystnych wag, które przypisane są temu

6 J. Gobat, M. Yanase, J. Maloney, The Net Stable Funding Ratio: Impact and Issues for Consideration, "IMF Working Paper" 2014, WP/14/106, www.imf.org, dostęp 10.02.2015.

7 P. Niedziółka, Skuteczny nadzór nad agencjami ratingowymi jako warunek sine qua non osiagnięcia celów europejskiej unii bankowej, w: Unia bankowa, red. M. Zaleska, Difin, Warszawa 2013, s. 110-125. 
rodzajowi pasywów. Jednocześnie zdaniem np. A.W. Hartlage wzmożone zainteresowanie preferowanymi (zgodnie z zasadami kalkulacji LCR) źródłami finansowania może zdestabilizować te rynki (np. rynek depozytów detalicznych, co dodatkowo w wypadku wzrostu poziomu oszczędności spowoduje spadek konsumpcji, negatywnie oddziałujący na tempo wzrostu gospodarczego) i przyczynić się do spadku stabilności sektora bankowego ${ }^{8}$.

Inną negatywną konsekwencją wprowadzenia LCR może okazać się redukcja rentowności banków wskutek między innymi spowolnienia tempa akcji kredytowej (determinowanego zaostrzeniem wymogów kapitałowych oraz zmianą struktury zaangażowania banków w kierunku płynnych papierów wartościowych, aby zbudować wymagany zasób HQLA), co finalnie przekłada się na spadek tempa wzrostu gospodarczego.

Banki uczestniczące w badaniu EBA w 2012 r. charakteryzowały się niedoborem stabilnych źródeł finansowania na poziomie 1,93 tryliona EUR, choć średnia wartość NSFR sięgała wówczas $90 \%$. To z kolei stanowi zagrożenie dla wzrostu portfela kredytów długoterminowych, któremu powinny odpowiadać stabilne źródła finansowania9.

Po zaostrzeniu wymogów kapitałowych oraz wprowadzeniu norm płynności banki podejmą zapewne działania dostosowawcze. Uważa się, że procesy te oznaczać mogą ${ }^{10}$ :

- dążenie do wydłużenia średniego okresu wymagalności zobowiązań, korespondującego ze średnim okresem zapadalności aktywów, aby sprostać normie NSFR - powyższe dostosowanie wpłynie na wzrost kosztu pozyskiwania środków przez banki, co może przełożý się na wzrost marż kredytowych (przynajmniej dla ekspozycji długoterminowych),

- zwiększenie udziału depozytów od osób fizycznych kosztem depozytów od osób prawnych, co wpłynie na zmiany w strukturze oprocentowania tych wkładów - jednocześnie banki, które nie posiadają sieci detalicznej i uzależnione są od finansowania $\mathrm{w}$ formie depozytów przedsiębiorstw i samorządów, zmuszone zostaną do zwiększenia stanu tych środków, co z kolei nie będzie korzystne z punktu widzenia ich rentowności,

8 A.W. Hartlage, The Basel III Liquidity Coverage Ratio and Financial Stability, "Michigan Law Review" 2012, Vol. 111, No. 3, s. 453-484, www.michiganlawreview.org, dostęp 11.02.2015. Powyższą tezę potwierdza również raport $\mathrm{PwC}$, opublikowany po uzgodnieniu ostatecznej wersji sposobu kalkulacji NSFR w październiku 2014 r. - Ten key points from Basel's final NSFR, PwC, $5^{\text {th }}$ November 2014, www.pwc.com, dostęp 08.01.2015.

9 New Bank Liquidity..., op.cit., s. 13.

${ }^{10}$ A.W. Hartlage, op.cit.; M. Marcinkowska, P. Wdowiński, S. Flejterski, S. Bukowski, M. Zygierewicz, Wplyw regulacji sektora bankowego na wzrost gospodarczy - wnioski dla Polski, „Materiały i Studia” 2014, nr 305, s. 91, 96. 
- transakcje swap pomiędzy bankami i zakładami ubezpieczeń, których efektem byłoby zwiększenie zasobu HQLA w portfelach banków,

- potencjalne ograniczenie akcji kredytowej z uwagi na konieczność zastąpienia tego rodzaju aktywów zasobem HQLA.

\section{Wpływ wprowadzenia norm płynności na sektor bankowy w Polsce}

Obowiązujące banki normy płynności wprowadzono w Polsce już w $2008 \mathrm{r}$. Ich istota i cele wprowadzenia zasadniczo zbliżone są do LCR i NSFR, lecz sposób estymacji znacząco odbiega od wskaźników rekomendowanych przez BKNB. Różnica tkwi przede wszystkim w dopuszczonej przez polski nadzór finansowy uznaniowości klasyfikacji poszczególnych rodzajów aktywów i pasywów, podczas gdy kalkulacja LCR oraz NSFR opiera się na z góry ustalonych wagach. Dodatkowo zgodnie z Bazyleą III oraz CRD/CRR linie kredytowe w instytucjach finansowych nie stanowią stabilnego źródła finansowania, co oznacza, że wymagają one pokrycia w płynnych aktywach ${ }^{11}$. Ukierunkowanie banków w Polsce na zarządzanie płynnością na pięć lat przed implementacją normy LCR, pomimo rozbieżności w konstrukcji wskaźników, nie powinno zatem spowodować istotnych perturbacji i działań zmierzających do radykalnej zmiany struktur bilansów. Zgoła inaczej wygląda sytuacja w krajach, w których wcześniej nie funkcjonowały jakiekolwiek kwantytatywne wymogi w zakresie płynności. Jednocześnie należy zauważyć, że w wypadku polskiego sektora bankowego mniejsze znaczenie ma wprowadzenie normy LCR (większość banków już w 2014 r. spełniało ją na poziomie przekraczającym 100\%), natomiast wypełnienie wskaźnika NSFR, oznaczające ograniczenie możliwości transformacji terminów, może być trudne do realizacji w krótkim okresie, o ile nie zostaną rozpoczęte działania dostosowawcze.

Kluczowe znaczenie dla kształtu norm płynności będzie miał lokalny (krajowy) nadzór finansowy, gdyż w świetle art. 8 CRR (pod zdefiniowanymi w ww. rozporządzeniu warunkami) właściwe władze nadzorcze mogą zrezygnować z obowiązku stosowania norm płynności w odniesieniu do podmiotów zależnych od banków działających w UE oraz sprawować nad nimi nadzór jako nad wydzieloną podgrupą

\footnotetext{
${ }^{11}$ Ibidem, s. 159.
} 
płynnościową ${ }^{12}$. Oznacza to możliwość wyłączenia przez KNF większości zarejestrowanych w Polsce banków z obowiązku estymacji LCR oraz NSFR. Tworzenie grup płynnościowych może w praktyce skutkować przeniesieniem systemu zarządzania płynnością na poziom jednostki dominującej, czego prawdopodobieństwo staje się szczególnie wysokie w odniesieniu do banków lokalnych, funkcjonujących w systemach finansowych o relatywnie niewielkich zasobach HQLA, posiadających jednostkę dominującą w kraju, którego system finansowy w większym stopniu odpowiada charakterystyce modelu anglosaskiego ${ }^{13}$.

Pozostawienie wymogu odnoszącego się do norm płynnościowych na poziomie skonsolidowanym nie musi jednak oznaczać koncentracji płynnych aktywów w jednostce dominującej (co byłoby korzystne z punktu widzenia łatwości zarządzania płynnością), jeśli grupa zamierza przypisać koszty związane z utrzymywaniem płynnych, ale niezbyt rentownych aktywów do jednostek zależnych ${ }^{14}$. Decyzja o utrzymywaniu wymogu w zakresie HQLA w określonej jednostce (konsolidującej lub zależnej) determinuje popyt na instrumenty zaliczane do HQLA na tym rynku (zakładając, że najmniej korzystne z punktu widzenia banku jest utrzymywanie HQLA w formie środków pieniężnych), a to oddziałuje na ich ceny, a także na ceny walorów, które banki będą zmuszone wyprzedawać. Należy jednocześnie zauważyć, że spektrum notowanych w Polsce instrumentów, które można zaliczyć do zasobu HQLA, jest znacznie węższe niż w krajach charakteryzujących się bardziej rozwiniętym rynkiem komercyjnych oraz municypalnych papierów dłużnych, a także np. listów zastawnych (walorów innych niż emitowane przez skarb państwa i bank centralny).

Pierwsze badanie poświęcone wpływowi norm płynności na polski sektor bankowy UKNF przeprowadził na podstawie danych banków na koniec czerwca $2011 \mathrm{r}$. Wówczas analizie poddano 44 banki. Wyniki tego testu przedstawia tabela 3.

$\mathrm{Z}$ badania, którego rezultaty przedstawiono w tabeli 3 , wynika istotny niedobór stabilnych źródeł finansowania. Problem jest o tyle istotny, że oprócz funduszy własnych, póki co na rynku polskim stabilne źródła finansowania banków stanowią margines. Właściwie banki nie oferują depozytów na okres powyżej roku (odróżnia to polski system bankowy od systemów w innych krajach UE, w tym zwłaszcza $\mathrm{w}$ Niemczech) i nie emitują średnioterminowych papierów dłużnych (np. w formie listów zastawnych). Jeśli popyt na średnioterminowe depozyty i papiery dłużne

12 Rozporządzenie Parlamentu Europejskiego i Rady (UE) nr 575/2013 z dnia 26 czerwca 2013 r. w sprawie wymogów ostrożnościowych dla instytucji kredytowych i firm inwestycyjnych, zmieniające rozporządzenie (UE) nr 648/2012, Dz. U. UE nr 176/1 z dnia 27.06.2013.

13 A. Jakubiak, Wptyw Bazylei III i innych nowych regulacji unijnych i polskich na politykę kredytowa i sytuację instytucjonalna sektora bankowego $w$ Polsce, w: Zmiany regulacji a rozwój sektora bankowego, „Zeszyty BRE Bank-CASE" 2012, nr 120, s. 17.

${ }^{14}$ M. Marcinkowska, P. Wdowiński, S. Flejterski, S. Bukowski, M. Zygierewicz, op.cit., s. 90. 
emitowane przez banki okaże się niewystarczający lub cena takiego finansowania okaże się zbyt wysoka, banki będą bardziej selektywnie podchodzić do udzielania kredytów długoterminowych, co z kolei stanowić może zagrożenie dla inwestycji w przedsiębiorstwach oraz rozwoju budownictwa mieszkaniowego. Ograniczony popyt na depozyty długoterminowe oraz papiery dłużne wynikać może natomiast $z$ dotychczasowego braku bodźców do długoterminowego oszczędzania przez instytucje, dla których inwestycje długoterminowe co do zasady stanowiłyby kluczową część portfela. Z kolei problemem dla banków w Polsce, związanym z możliwością wypełnienia normy LCR, jest preferowanie depozytów detalicznych, których prawdopodobieństwo odpływu w okresie kryzysu oceniono jako niższe od prawdopodobieństwa wycofania depozytów korporacyjnych i samorządowych - powyższe uwarunkowania mogą stać się zarzewiem wojny depozytowej. Podsumowując, zaakcentować należy negatywne oddziaływanie wdrażanych regulacji szczególnie dla przedsiębiorstw, ze względu na potencjalnie wyższy koszt średnio- i długoterminowych kredytów finansujących inwestycje oraz niższą dochodowość depozytów, które odtąd staną się mniej atrakcyjną formą finansowania działalności bankowej od depozytów detalicznych ${ }^{15}$.

Tabela 3. Skutki wprowadzenia LCR i NSFR dla banków uniwersalnych w Polsce (wg stanu na 30.06.2011)

\begin{tabular}{|l|c|c|}
\cline { 2 - 3 } \multicolumn{1}{c|}{} & LCR & NSFR \\
\hline Liczba banków, które nie spełniły normy & 14 & 11 \\
\hline Średnia wartość wskaźnika & $150 \%$ & $107 \%$ \\
\hline Niedobór HQLA (w mld PLN) & 15,5 & Nd \\
\hline Niedobór stabilnych źródeł finansowania (w mld PLN) & Nd & 34,3 \\
\hline
\end{tabular}

Źródło: Opracowanie własne na podstawie A. Jakubiak, Wplyw Bazylei III i innych nowych regulacji unijnych i polskich na politykę kredytową i sytuację instytucjonalną sektora bankowego w Polsce, UKNF, 12.04.2012, s. 12, https://www.knf.gov.pl/Images/Wplyw_Bazylei_III_tcm75-30765.pdf

W 2014 r. NBP przeprowadził analizę wpływu wprowadzenia zaostrzonych wymogów kapitałowych oraz norm płynności na koszt kredytu w Polsce oraz na tempo wzrostu PKB. W badaniu wzięło udział 37 banków (dane z bazy Bankscope), a okresem analizy objęto lata 2004-2011. Identyfikując kanały transmisji wdrożenia wymogów płynnościowych na sferę realną, zwrócono uwagę na spadek podaży kredytów negatywnie oddziałujący na $\mathrm{PKB}$ oraz mechanizm zwrotny w postaci wpływu spadku

${ }_{15}$ M. Stańczuk, Możliwe implikacje wejścia w życie pakietu regulacyjnego Bazylea III dla polskich banków komercyjnych, w: Zmiany regulacji a rozwój sektora bankowego, „Zeszyty BRE Bank-CASE” 2012, nr 120, s. $25-26$. 
PKB na zmniejszenie się popytu na kredyt (dodatkowym czynnikiem wywołującym spadek popytu na kredyt jest wzrost marż kredytowych). W badaniu posłużono się jednorównaniowym modelem panelowym (pełniącym funkcję mikroekonomicznego uzupełnienia analizy, subsydiarnego w stosunku do modelu makroekonometrycznego) oraz wielorównaniowym kwartalnym modelem makroekonometrycznym, zakładając, że koszty zwiększenia wymogów kapitałowych oraz wprowadzenia norm płynności zostaną w całości przeniesione na klientów banków ${ }^{16}$ (współczynnik wypłacalności oraz współczynniki płynności krótko- i długoterminowej są zmiennymi objaśniającymi oprocentowanie kredytów). Stosując każdy z modeli, wykazano dodatni i statystycznie istotny wpływ podwyższenia współczynnika wypłacalności oraz wprowadzenia norm płynności na oprocentowanie kredytów. W modelu symulacyjnym (makroekonometrycznym) posłużono się normami płynności obowiązującymi w Polsce (mniej restrykcyjnymi niż wskaźniki LCR i NSFR). Wyniki badania, opartego na hipotezie kosztowej, a zakładającego wzrost zagregowanego współczynnika wypłacalności o 4 p.p. oraz współczynników płynności krótkoterminowej i długoterminowej o 50 p.p. wskazują, że realny PKB może obniżyć się w pierwszym roku o $0,05 \%$, a w kolejnych latach odpowiednio o $0,42 \%, 0,73 \%$ oraz $0,53 \%$. Jednocześnie wyizolowanie wzrostu zagregowanego współczynników M2 i M4 w relatywnie niewielkim stopniu wpływa na zmniejszenie się realnego PKB (brak wpływu w pierwszym roku, w kolejnych latach spadek odpowiednio o $0,001 \%, 0,005 \%$ oraz $0,009 \%)$. Zatem oddziaływanie zmian współczynnika wypłacalności ocenić należy jako istotniejsze, tym bardziej, że wprowadzenie normy płynności długoterminowej (zwłaszcza w formule NSFR) może mieć pozytywny wpływ na współczynnik wypłacalności (konwersja części długoterminowych, obarczonych podwyższonym ryzykiem, aktywów na zasób HQLA). Należy jednocześnie pamiętać, że spadek PKB (determinowany efektem kosztowym) wywołuje obniżenie się konsumpcji, inwestycji oraz akcji kredytowej. Podsumowując, podwyższenie wymogów kapitałowych oraz wprowadzenie norm płynnościowych o charakterze kwantytatywnym wpłynie raczej niekorzystnie na poziom i tempo wzrostu gospodarczego, natomiast oddziaływanie wdrażanych zmian na stabilność finansową należy ocenić jako potencjalnie ograniczone, co wynika głównie z tego, iż polski system bankowy już przed wejściem w życie Bazylei III oraz pakietu CRD/CRR uznawany był za relatywnie stabilny ${ }^{17}$.

\footnotetext{
${ }^{16}$ Np. badanie przeprowadzone w 2011 r. przez MFW dowiodło, że jedynie z powodu zwiększenia wymogów kapitałowych największe banki podwyższą cenę finansowania o 16 p.b. (wynik jest zbieżny z cytowanymi $\mathrm{w}$ niniejszym opracowaniu wynikami analogicznych badań przeprowadzonych przez BKNB) - T.F. Cosimano, D.S. Hakura, Bank behavior in response to Basel III: A cross-country analysis, IMF Institute, May 2011, s. 19, papers.ssrn.com, dostęp 10.02.2015.

17 Zob. M. Marcinkowska, P. Wdowiński, S. Flejterski, S. Bukowski, M. Zygierewicz, op.cit., s. 115-196.
} 


\section{Normy płynności a rozwój gospodarczy}

Kilkunastoprocentowe (narastająco) utraty PKB w okresie kryzysu są najczęściej wynikiem nakładania się kryzysu bankowego na recesję w sferze realnej. Zdecydowanie mniej dotkliwe i krótsze okazują się kryzysy gospodarcze, którym nie towarzyszą perturbacje funkcjonowania systemu bankowego.

Intencją BKNB było wprowadzenie regulacji, dzięki którym możliwe byłoby rozdzielenie od siebie kryzysu bankowego i kryzysu w sferze realnej, jak również ograniczenie prawdopodobieństwa powstania kryzysu bankowego i złagodzenie jego skutków.

Badanie przeprowadzone przez BKNB w 2010 r. wskazuje na znaczące korzyści $\mathrm{z}$ redukcji prawdopodobieństwa powstania kryzysu bankowego (mierzone w procentach rocznego $\mathrm{PKB})$.

Tabela 4. Oczekiwane roczne korzyści z tytułu redukcji prawdopodobieństwa powstania kryzysu

\begin{tabular}{|c|c|c|c|}
\hline $\begin{array}{c}\text { Redukcja } \\
\text { prawdopodobieństwa } \\
\text { powstania kryzysu (w p.p.) }\end{array}$ & $\begin{array}{c}\text { Kryzysy bez trwałego } \\
\text { wpływu na produkcje }\end{array}$ & $\begin{array}{c}\text { Kryzysy z długotrwałym } \\
\text { lub niewielkim wpływem } \\
\text { na produkcję }\end{array}$ & $\begin{array}{c}\text { Kryzysy z długotrwałym } \\
\text { istotnym wpływem } \\
\text { na produkcje }\end{array}$ \\
\hline 1 & 0,19 & 0,63 & 1,58 \\
\hline 2 & 0,38 & 1,26 & 3,16 \\
\hline 3 & 0,57 & 1,89 & 4,74 \\
\hline
\end{tabular}

Źródło: An assessment of the long-term economic impact of stronger capital and liquidity requirements, BIS, August 2010, s. 13.

Wyliczenia zawarte w tabeli 4 wynikają z przemnożenia poziomu redukcji prawdopodobieństwa wystąpienia kryzysu przez zaktualizowaną wartość spadku produkcji.

Jeśli w świetle danych zawartych w tabeli 4 redukcja prawdopodobieństwa wybuchu kryzysu bankowego jest tak istotna (przynosi tak znaczące korzyści), powstaje pytanie o sposoby tego dokonania. Badania BKNB dowodzą, iż zaostrzenie wymogów kapitałowych oraz wdrożenie norm płynności są rozwiązaniami skutkującymi zmniejszeniem prawdopodobieństwa kryzysu. Powyższe wnioski ilustruje rysunek 1. 
Rysunek 1. Prawdopodobieństwo kryzysu bankowego w zależności od TCE/RWA ${ }^{18}$ przy NSFR = 1



Źródło: Opracowanie własne na podstawie An assessment of the long-term economic impact of stronger capital and liquidity requirements, BIS, August 2010, s. 15.

Z rysunku 1 wynika, że zaostrzenie wymogów kapitałowych oraz norm płynności istotnie obniża ryzyko kryzysu bankowego, lecz redukcja ta nie następuje równomiernie. Większe efekty osiągane są dla wzrostu TCE/RWA w przedziale 6-10\%.

Uwzględnienie wyłącznie zaostrzenia wymogów kapitałowych przyniosłoby wyniki w mniejszym stopniu satysfakcjonujące od zaprezentowanych na rysunku 1 , co pokazuje rysunek 2 .

Rekomendowane przez BKNB wartości współczynników adekwatności kapitałowej oraz płynności charakteryzują się tym, że ich ewentualne zwiększanie będzie wprawdzie skutkować marginalnymi korzyściami, lecz będą to korzyści malejące. Symulacja przeprowadzona przez BKNB prowadzi również do wniosku, iż z perspektywy stabilności systemu bankowego większe korzyści osiąga się poprzez jednoczesne (nawet niezbyt radykalne) zaostrzenie wymogów kapitałowych i norm płynnościowych w stosunku do istotnego zwiększenia wymogu kapitałowego.

Wyniki badania przeprowadzonego przez BKNB zostały w dużej mierze potwierdzone przez S. Kruga, M. Lengnicka i H.-W. Wohltmanna, którzy zweryfikowali wpływ wprowadzenia nowych wymogów kapitałowych oraz norm płynności na stabilność

18 TCE (Tangible Common Equity), czyli kapitał własny pomniejszony o wartości niematerialne i prawne oraz wartość firmy. RWA (Risk Weighted Assets), czyli aktywa ważone ryzykiem. 
finansową - indeks stabilności finansowej ${ }^{19} \mathrm{w}$ wybranych wariantach kształtował się następująco ${ }^{20}$ :

- wprowadzenie LCR (z wymaganą wartością 100\%) przy braku innych korekt skutkuje wzrostem indeksu z 26,1 do 34,3,

- wprowadzenie LCR (z wymaganą wartością 100\%) przy zwiększeniu wymogów kapitałowych wyłącznie dla banków o znaczeniu systemowym skutkuje wzrostem indeksu z 26,1 do 41,3.

Rysunek 2. Prawdopodobieństwo kryzysu bankowego w zależności od TCE/RWA (bez wymogu utrzymania NSFR na minimalnym poziomie)

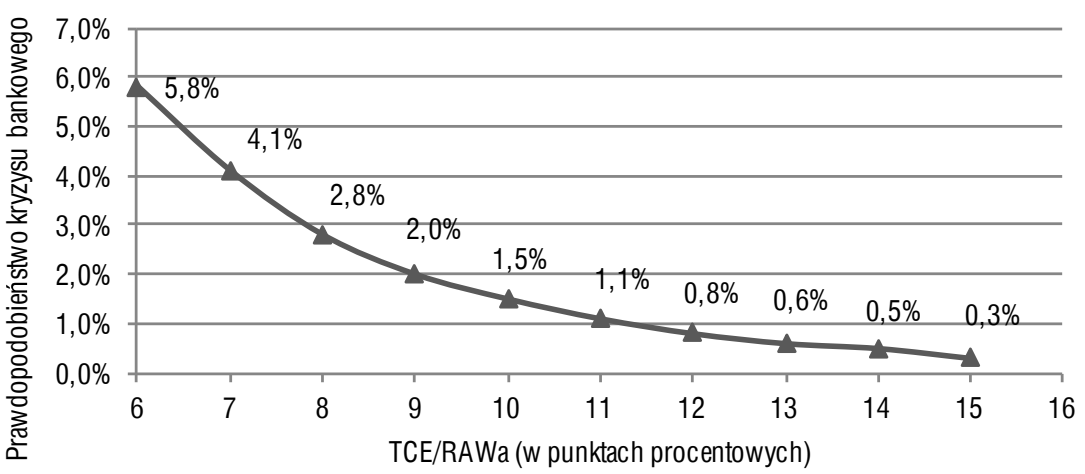

Źródło: Opracowanie własne na podstawie An assessment of the long-term economic impact of stronger capital and liquidity requirements, BIS, August 2010, s. 15.

Podobnie jak w innych badaniach, istotny wzrost indeksu stabilności ma miejsce dzięki równoległemu wprowadzeniu norm płynnościowych (uwzględniono wyłącznie LCR) oraz zaostrzeniu wymogów kapitałowych (np. samo podniesienie współczynnika wypłacalności kalkulowanego na podstawie kapitału podstawowego z 2\% do 4,5\% skutkuje zwiększeniem indeksu do 41,3 (nieco więcej niż w wypadku wdrożenia wyłącznie norm płynnościowych, podczas gdy połączenie zaostrzenia wymogów kapitałowych i wprowadzenia norm płynnościowych oznaczałoby wzrost indeksu do 78,6).

Z punktu widzenia pojedynczych banków implementacja norm płynności nie jest korzystna, gdyż oznacza utratę części dochodu wskutek konieczności dostosowania struktury aktywów do wymogów HQLA (o ile luka ta nie zostanie skompensowana

\footnotetext{
19 Indeks stabilności S. Kruga, M. Lengnicka i H.-W. Wohltmanna wskazuje na odsetek banków (próbę stanowiło 4500 banków), które przetrwały po przeprowadzeniu 500 symulacji.

20 S. Krug, M. Lengnick, H.-W. Wohltmann, The impact of Basel III on financial (In) stability, September 2013, s. 25, www.researchgate.net, dostęp 10.02.2015.
} 
dochodem wynikającym z podwyższenia marż kredytowych). Z perspektywy gospodarki sytuacja wygląda natomiast inaczej, zwłaszcza gdy koszt wprowadzenia nowych wymogów (płynnościowych i kapitałowych) zostanie skonfrontowany z kosztami kryzysu $^{21}$. Należy jednocześnie wspomnieć, że przygotowany przez BKNB scenariusz zakłada, iż koszty implementacji norm płynności zostaną przeniesione na klientów banków. BKNB szacuje, że w związku z wejściem w życie normy NSFR marża kredytowa wzrośnie o 14 p.b. Z kolei uwzględnienie zaostrzonych wymogów kapitałowych oraz nowych norm płynności w koszcie finansowania przedsiębiorstw według obliczeń BKNB może przynieść spadek PKB o 0,08\%. Wskazaną powyżej wartość traktować należy jako graniczną, gdyż nie ma pewności, czy banki zdecydują się na podwyższenie marż swoim klientom ${ }^{22}$.

Przeniesienie przez banki obciążeń związanych z wprowadzeniem norm LCR i NSFR na swoich klientów nie jest jedyną negatywną konsekwencją reformy, nazywanej Bazyleą III. Liczyć należy się również z delewarowaniem wynikającym z jednej strony z konieczności zamiany części niepłynnych aktywów na zasób HQLA, $\mathrm{z}$ drugiej strony nieodnawianiem lub nieudzielaniem ekspozycji długoterminowych, które nie mają pokrycia w stabilnych źródłach finansowania. O ile przedsiębiorstwa (zwłaszcza duże) mogą skorzystać $\mathrm{z}$ alternatywnych form finansowania (np. obligacje, fundusze private equity), o tyle w największym stopniu problem dotyka osób fizycznych, które w tej sytuacji mogą się stać klientami instytucji parabankowych (wówczas koszt pozyskania środków gwałtownie wzrośnie).

\section{Podsumowanie}

Próbując ocenić wpływ wprowadzenia norm płynności na sektor bankowy oraz sferę realną gospodarki, można sformułować następujące konkluzje:

- nowe wymogi wywołają działania dostosowawcze banków, redukując niedopasowanie między terminami zapadalności aktywów oraz wymagalności pasywów. Skutkiem tych przesunięć w bilansach banków może być redukcja rentowności działalności bankowej, o ile koszt utrzymania dodatkowego kapitału oraz zmiany struktur bilansów wskutek wprowadzenia norm płynności nie zostanie

${ }^{21}$ Korzyści netto (z punktu widzenia gospodarki) związane z wprowadzeniem pakietu Bazylea III wykazali również P. Angelini, L. Clerc, V. Curdia, L. Gambacorta, A. Gerali, A. Locarno, R. Motto, W. Roeger, S. Van den Heuvel, J. Vlcek, Basel III: Long-term impact on Economic Performance and Fluctuations, "The Mnchester School" 2015, Vol. 83, No. 2, s. 217-251.

${ }^{22}$ A.W. Hartlage, op.cit. 
przeniesiony na klientów. Inną konsekwencją może okazać się utrudnienie dostępu do finansowania długoterminowego. Wzrost kosztu kredytu i ograniczenie jego dostępności negatywnie oddziałują na wzrost gospodarczy,

- wprowadzenie norm płynności oraz zwiększenie wymogów kapitałowych istotnie obniża prawdopodobieństwo kryzysu bankowego, co stanowi rekompensatę za okresowe i nieznaczne obniżenie tempa wzrostu gospodarczego determinowane przyczynami wymienionymi w pierwszej konkluzji.

\section{Bibliografia}

An assessment of the long term economic impact of stronger capital and liquidity requirements, BIS, 2010.

Angelini P., Clerc L., Curdia V., Gambacorta L., Gerali A., Locarno A., Motto R., Roeger W., Van den Heuvel S., Vlcek J., Basel III: Long-term impact on Economic Performance and Fluctuations, "The Manchester School” 2015, Vol. 83, No. 2.

Basel III: The Liquidity Coverage Ratio and liquidity risk monitoring tools, BIS, 2013.

Basel III: The Net Stable Funding Ratio, BIS, October 2014.

Cosimano T.F., Hakura D.S., Bank behavior in response to Basel III: A cross-country analysis, IMF Institute, May 2011, papers.ssrn.com, dostęp 10.02.2015.

Gobat J., Yanase M., Maloney J., The Net Stable Funding Ratio: Impact and Issues for Consideration, "IMF Working Paper" 2014, WP/14/106, June 2014, www.imf.org, dostęp 10.02.2015.

Hartlage A.W., The Basel III Liquidity Coverage Ratio and Financial Stability, "Michigan Law Review" 2012, Vol. 111, No. 3, www.michiganlawreview.org, dostęp 10.02.2015.

International framework for liquidity risk measurement, standards and monitoring, BIS, 2010.

Jakubiak A., Wpływ Bazylei III I innych nowych regulacji unijnych i polskich na polityke kredytowa $i$ sytuacje instytucjonalna sektora bankowego $w$ Polsce, w: Zmiany regulacji a rozwój sektora bankowego, „Zeszyty BRE Bank-CASE” 2012, nr 120.

Kochaniak K., Płynność sektora bankowego w Polsce i znaczenie norm nadzorczych, „Annales Universitatis Mariae Curie Sklodowska" 2010, Lublin - Polonia, VOL. XLIV, 2 SECTIO H.

Koleśnik J., Bezpieczeństwo systemu bankowego, Difin, Warszawa 2011.

Krug S., Lengnick M., Wohltmann H.-W., The impact of Basel III on financial (In) stability, September 2013, www.researchgate.net, dostęp 10.02.2015.

Liquidity: A bigger challenge than capital, KPMG, 2012. 
Marcinkowska M., Wdowiński P., Flejterski S., Bukowski S., Zygierewicz M., Wpływ regulacji sektora bankowego na wzrost gospodarczy - wnioski dla Polski, „Materiały i Studia" 2014, nr 305.

Net Stable Funding Ratio finalised by the Basel Committee, BIS, 2014.

New Bank Liquidity Rules: Dangers Ahead, A Position Paper by EBA's Banking Stakeholder Group, EBA, October 2012, www.eba.europa.eu, dostęp 09.02.2015.

Niedziółka P., Skuteczny nadzór nad agencjami ratingowymi jako warunek sine qua non osiagnięcia celów europejskiej unii bankowej, w: Unia bankowa, red. M. Zaleska, Difin, Warszawa 2013.

Possible further changes to the Capital Requirements Directive, Commission Services Staff Working Document, EU, November 2011.

Report on the results of Basel III monitoring exercise as of 31 December 2013, EBA, 2014.

Rozporządzenie Parlamentu Europejskiego i Rady (UE) nr 575/2013 z dnia 26 czerwca 2013 r. w sprawie wymogów ostrożnościowych dla instytucji kredytowych i firm inwestycyjnych, zmieniające rozporządzenie (UE) nr 648/2012, Dz. U. UE nr 176/1 z dnia 27.06.2013.

Smith D., Jennings-Mares J., Liquidity Coverage Ratio: New Basel Measurement Published, Morrison-Foerster, www.mofo.com, dostęp 10.10.2013.

Stańczuk M., Możliwe implikacje wejścia w życie pakietu regulacyjnego Bazylea III dla polskich banków komercyjnych, w: Zmiany regulacji a rozwój sektora bankowego, „Zeszyty BRE Bank-CASE” 2012, nr 120.

Ten key points from Basel's final NSFR, PwC, 5 November 2014, www.pwc.com, dostęp 08.01.2015.

Unia bankowa, red. M. Zaleska, Difin, Warszawa 2013.

Wplyw regulacji sektora bankowego na wzrost gospodarczy - wnioski dla Polski, „Materiały i Studia NBP” 2014, nr 305.

Wyniki ilościowego badania wptywu Bazylei III na polskie sektor bankowy (PLQIS), PwC, 2011.

\section{The Analysis of Potential Benefits and Negative Consequences of the LCR's and NSFR's Implementation in European Banks}

The introduction of liquidity ratios on the banking sector and the real economy will lead to adaptation of the banks. Mismatch between the maturity of assets and liabilities will be subject to reduction. These shifts in the banks' balance sheets may result in diminishing profitability of banks as long as the cost of maintaining additional capital and balance sheet structure changes will not be passed on 
to customers. Another consequence may be an impediment to access of nonfinancial entities to long-term financing. Thus, increased cost of credit and reduction of its availability in the short term will have negative impact on economic growth while introduction of liquidity standards and new capital requirements significantly reduces the probability of a banking crisis, which compensates for interim and slight decrease in the growth rate.

Keywords: liquidity risk, Basel III, LCR, NSFR, impact of the liquidity regulations on the banks

\section{L'analyse des avantages potentiels et des conséquences négatives de la mise en œuvre du LCR et NSFR dans les banques européennes}

L'introduction des ratios de liquidité pour le secteur bancaire et l'économie réelle conduira à l'adaptation des banques. Le décalage entre la maturité des actifs et passifs sera soumis à la réduction. Ces changements dans les bilans des banques pourraient se traduire par une baisse de rentabilité des banques tant que le coût du maintien des capitaux additionnels et les changements de la structure du bilan ne seront pas répercutés sur les clients. Une autre conséquence pourrait être un obstacle à l'accès des entités non financières au financement à long terme. Ainsi, l'augmentation du coût du crédit et la réduction de sa disponibilité à court terme auront un impact négatif sur la croissance économique tandis que l'introduction des normes de liquidité et de nouvelles exigences de fonds réduit de manière significative la probabilité d'une crise bancaire, ce qui compense la diminution provisoire et légère du taux de croissance.

Mots-clés: le risque de liquidité, Bâle III, LCR, NSFR, l'impact des règles de liquidité sur les banques

\section{Анализ потенциальных выгод и негативных последствий применения LCR и NSFR в европейских банках}

Введение коэффициентов ликвидности в банковском секторе повлияет на реальную экономику и приведет к адаптационному поведению банков. Уменьшится разрыв по срочности активов и пассивов. Результатом сдвигов в балансах банков может стать спад прибыльности банков, длившийся до 
тех пор, пока расходы на содержание дополнительного капитала и изменения в структуре баланса не будут перенесены на клиентов. Другим следствием может стать сокращение доступа нефинансовых организаций к долгосрочному финансированию. Таким образом, увеличение стоимости кредита и снижение его доступности в краткосрочной перспективе будет иметь негативное влияние на экономический рост. Внедрение стандартов по ликвидности и новых требований к капиталу значительно снижает вероятность банковского кризиса, что компенсирует временное и незначительное падение темпов экономического роста.

Ключевые слова: риск ликвидности, Базель III, LCR, NSFR, влияние стандартов по ликвидности на банки 